\title{
Interdisciplinary food-related academic programs: A 2015 snapshot of the United States landscape
}

\author{
Jennifer C. Hartle, ${ }^{\mathrm{a}, \mathrm{b}} *$ Schyler Cole, ${ }^{\mathrm{c}}$ Paula Trepman, ${ }^{\mathrm{d}}$ Benjamin W. Chrisinger, ${ }^{\mathrm{b}}$ \\ and Christopher D. Gardner ${ }^{b}$ \\ Stanford University
}

Submitted July 27, 2017 / Accepted July 28, 2017 / Published online December 13, 2017

Citation: Hartle, J. C., Cole, S., Trepman, P., Chrisinger, B. W., \& Gardner, C. D. (2017).

Interdisciplinary food-related academic programs: A 2015 snapshot of the United States

landscape. Journal of Agriculture, Food Systems, and Community Development, 7(4), 35-49.

http://dx.doi.org/10.5304/jafscd.2017.074.006

Copyright (C) 2017 by New Leaf Associates, Inc.

\begin{abstract}
Interdisciplinary food-related research and study is a growing field in academia. Each year, more universities add departments, courses, majors, and minors focused on studying food and society and the complexities of growing, processing, distributing, accessing, and consuming food. In this commentary, we present our exploratory findings about interdisciplinary food-related academic programs, including food studies and food systems programs in the United States. This cross-sectional research developed a snapshot of the 2015 landscape of interdisciplinary food-related academic

\footnotetext{
a $*$ Corresponding author: Jennifer C. Hartle, Stanford Prevention Research Center, School of Medicine, Stanford University.

Hartle is now at the Department of Health Science and Recreation, San Jose State University; One Washington Square; San Jose, CA 95192-0052 USA; +1-408-924-3294; Lennifer.hartle@sjsu.edu

b Stanford Prevention Research Center, School of Medicine, Stanford University.

c Stanford University.

d School of Medicine, Stanford University.
}

programs, provided a preliminary examination of their educational offerings, and will inform future research opportunities. In this formative study, we found 82 interdisciplinary food-related undergraduate programs focused on food. Nineteen program majors, minors, or concentrations had a core disciplinary focus on sustainable agriculture. "Food studies" and "food systems" were the primary focus of 15 undergraduate programs. We found 58 interdisciplinary food-related graduate programs and extracted information on their course offerings. Organizing courses into nine course categories, 78 percent of the programs offered courses in two to five categories, and 22 percent offered courses in six to eight categories. Few courses integrated material from multiple disciplines into a single course, suggesting that these interdisciplinary programs stemmed from

\section{Disclosure}

Jennifer C. Hartle and Benjamin W. Chrisinger were supported by the National Institutes of Health T32 HL007034 Grant; Paula Trepman was supported by the Leadership in Health Disparities Program, Stanford Center of Excellence in Diversity in Medical Education. 
traditional academic silos. Based on this preliminary work, we propose to further investigate the interdisciplinary nature of food-related academic programs, map their growth trajectory, and solicit feedback from faculty and administrators about their challenges in establishing and maintaining these programs. In future research, we are also interested in exploring job options for graduates of food-related academic programs to inform recruitment strategies and courses of study.

\section{Keywords}

Academic Programs; Agriculture; Food Studies; Food Systems; Higher Education; Nutrition; Sustainability; United States; Universities

\section{Introduction}

Interdisciplinary food-related research and study is a growing field in academia. Each year, the number of universities with departments, courses, majors, and minors focused on studying food and its relationship to culture and society, and the complexities of growing, processing, distributing, accessing, and consuming food, increases (Holt, 2015; Jacobsen et al., 2012; Spiegel, 2012; Weissman, Gantner, \& Narine, 2012). This development has been motivated by student desire to learn interdisciplinary approaches to studying food (Holt, 2015; Jacobsen et al., 2012; Spiegel, 2012).

Traditionally, food-related programs have been housed in a single department or school and organized into such fields as Agricultural Science, Food Science, Nutrition Science and Dietetics, and Culinary Arts and Hospitality. Some programs function within their historic missions as land-grant universities that were established in the 1860s to teach applied agricultural subjects (Jacobsen et al., 2012; Spiegel, 2012). In contrast, the modern wave of interdisciplinary food-related programs in higher education— "Food Studies" programs—draw from humanities, social sciences, and natural sciences, following in the footsteps of interdisciplinary programs such as Women's Studies and American Studies that employ multiple academic sectors to solve complex social and political challenges (Berg, Nestle, \& Bentley, 2003; Cargill, 2005).

The impetus to develop many of these interdisciplinary food-related academic programs stems from a growing awareness of the relationship between food choices and their impact on local and global issues such as climate change, environmental sustainability, public health, water shortages, and animal rights and welfare (McIntyre, Herren, Wakhungu, \& Watson, 2009; Neff, 2014; Neff, Merrigan, \& Wallinga, 2015; Pretty et al., 2010; Tomich et al., 2011; Whitmee et al., 2015). As the world population grows, develops, and globalizes, there is an increasing strain on the finite land, water, and energy resources used in the food system (Godfray et al., 2010). Single disciplines are limited in their capacity to address these changing demands on the food supply. One approach to conceptualize these multifaceted issues is to apply systems theory to food systems issues (Sobal, Khan, \& Bisogni, 1998). Systems theory takes a big-picture approach to studying the various interrelated components of a system, including cycles, chains, and webs (Sobal et al., 1998). This method, referred to as a "food systems approach," often draws on methods from multiple disciplines to solve complex food system issues. These problems include how to produce an adequate caloric intake, reduce the prevalence of access and distribution challenges, and assure the environmental sustainability for future generations. Some food systems approaches focus on methods within a discipline, while interdisciplinary food systems approaches break down traditional academic silos and teach systems-level methods to problem solving across two or more academic fields.

The first programs in the United States to address interdisciplinary food-related studies and research began in the 1990s at New York University (NYU) and Boston University (BU). Building on an academic program established in the 1920s, NYU currently has a Department of Nutrition, Food Studies, and Public Health in its Steinhardt School of Culture, Education, and Human Development. Initiated by the politically engaged nutritionist Marion Nestle, this department has undergraduate, graduate, and doctoral degree programs in Food Studies in the fields of Nutrition and Dietetics, Food Studies, Food and Restaurant Management, and Public Health (Berg et al., 2003; Nestle \& McIntosh, 2010). Renowned chefs Julia Child and Jacques Pépin cofounded Boston Uni- 
versity's Gastronomy program, which now allows students to choose from multiple focus areas for a Gastronomy master's degree or earn a graduate certificate in Food Studies (Boston University, n.d.). Since these early programs, numerous universities have developed and launched food studies programs, with a boom over the past decade.

To increase our understanding of the growing field of interdisciplinary food-related academic programs such as Food Studies, Food Systems, and Sustainable Agriculture, our exploratory research goal was to provide a strong foundation for further, more comprehensive research. In this research commentary, we offer a snapshot of the landscape of interdisciplinary food-related academic programs in the U.S. and their educational offerings. We welcome the involvement of representatives of any of these programs in future research.

\section{Methods}

We used a multipronged approach to identify interdisciplinary undergraduate and graduate foodrelated academic research and study programs in the U.S., including degree and certificate-conferring online programs. To identify interdisciplinary foodrelated academic programs, we established two criteria. First, the program had to publicly market itself in program descriptions as providing interdisciplinary coursework, and/or listings of the coursework had to be in two or more disciplines that address food-related issues. Second, the program had to be a formal academic program of an accredited public or private educational institution that awarded degrees and/or certificates.

For undergraduate programs, we included programs where students could major, minor, or have a concentration in food-related research and study. We excluded community college programs, any programs outside the U.S., and programs that were not yet enrolling students by December 2015 to simplify and focus our research. For graduate programs, we included master's, doctoral degree, or certificate programs.

With these criteria established, we reviewed lists of food and agriculture academic programs compiled by colleagues from the University of California (UC) at Berkeley, Davis, and Santa Cruz.
During this stage, we also reviewed food studies and food systems program lists from the Association for the Study of Food and Society, the Sustainable Agriculture Education Association, and the Inter-Institutional Network for Food, Agriculture and Sustainability. ${ }^{1}$ The programs gathered in this step were then analyzed to determine if they met our inclusion criteria. At this stage, 49 undergraduate programs and 39 graduate programs were identified.

To supplement this initial list, we performed an internet search using Google during February and March 2015 using the search terms "food studies undergraduate programs" and "food systems undergraduate programs," or "food studies graduate programs" and "food systems graduate programs." From the programs identified by the internet search terms, we reviewed the program description and course listings, if available, to confirm that the program was interdisciplinary. In this stage, an additional 23 undergraduate programs and six graduate programs were identified.

Finally, in fall 2015, we shared our aggregated list with food studies and food systems colleagues to confirm that we had identified known programs, leading to the addition of 10 undergraduate programs and 13 graduate programs.

Once an interdisciplinary food-related academic program was confirmed, we collected the following information: the department(s) and/or school(s) involved, degree awarded, program address and URL, program contact, details on an associated farm or garden program, and when the program was established. We reviewed course listings for undergraduate food-related academic programs when available, but chose not to catalog them as it was not always clear if the courses listed

\footnotetext{
${ }^{1}$ The food studies and food systems program lists were obtained at these sites:

- Association for the Study of Food and Society: http://www.food-culture.org/food-studies-programs/

- Sustainable Agriculture Education Association: http://www.sustainableaged.org/projects/degreeprograms/

- Inter-Institutional Network for Food, Agriculture and Sustainability: http://asi.ucdavis.edu/programs

Note that the sites have been updated since this study, so their current lists will not match the lists in this article.
} 
were necessary to fulfill school-wide or degree requirements.

For interdisciplinary graduate food-related academic programs, we obtained the required course listings. Our initial course categories were not developed a priori; instead, we developed course categories as we reviewed course listings. First, we distinguished "food studies" and "food systems" courses. Food studies described courses with a focus on cultural, historical, or other academic perspectives on food. For example, a food studies course might examine the importance of grains throughout the world, or issues around hormones in meat production. We defined food systems courses as those that either explicitly used "food systems" in the title or description, or contained subject matter that included a broader examination of the inputs to food production, distribution, and consumption. Their content tended to focus on examinations of current issues in the food system. We found considerable overlap between "food studies" and "food systems" courses, so we combined these categories in our final course groupings.

\section{Figure 1. Categorization Process for Interdisciplinary Food-Related Courses}

\begin{tabular}{|l|}
\hline Hard Sciences/Food Science/Laboratories \\
\hline Nutrition \\
Nutrition/Environment \\
Public Health \\
\hline \\
Business/Commerce \\
Community Development/Nonprofit Management/Leadership \\
Economics \\
Policy/Government \\
Statistics/Probability
\end{tabular}

Agriculture/Agribusiness

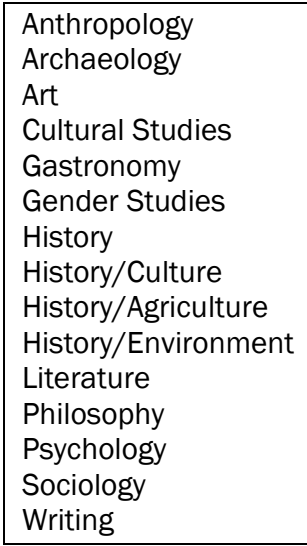

Biological and Physical Sciences

Public Health and Nutrition

Government/Policy/Economics

Agriculture/Agribusiness

Social Sciences

Methods Courses Supporting

Food-Related Research

Environment/Sustainability

Food Studies/Food Systems

Food Services/Hospitality/ Culinary Arts 
We also distinguished between "food science" and "food services" courses. Food science courses are focused on the chemical and biological characteristics of food and are more lab- and natural science-intensive, such as Food Chemistry and Food Microbiology Laboratory. Food services courses, such as Marketing and Purchasing, focus on the food-service industry through an economic, business, logistics, or managerial lens.

By aggregating offerings from similar disciplines, the original 33 course categories collapsed into an organizational structure that resulted in a final set of nine categories (see Figure 1). The course categories include (in order of prevalence): biological and physical sciences (including food sciences courses); public health and nutrition; government, policy, and/or economics; agriculture and agribusiness; social sciences; methods courses supporting food-related research; environment and sustainability; food studies and food systems; and food services, hospitality, and/or culinary arts.

\section{Results}

Presented below is information we compiled about interdisciplinary food-related academic degree programs in the United States, organized into undergraduate programs and graduate programs.

\section{Undergraduate Programs Identified}

We identified 83 undergraduate interdisciplinary food-related academic programs offered at 63 universities. The majority of these programs had their core focus in food production, with specializations in agricultural technology, sustainable agriculture, agroecology, horticultural science, plant science, soil science, crop science, and organic farming. We found 19 programs that focused on sustainable agriculture, eight programs self-described as "food systems programs," and seven programs with a "food studies" focus. Six of the programs were interdisciplinary environmental studies programs tied to sustainable agriculture or sustainable farming. There were 21 programs centered on nutrition and the preparation of food, including nutrition science, dietetics, culinary science, culinary arts, and food science. Four programs included a focus on the economic basis of the food system, including agricultural economics; food business economics; and economics related to development, sustainability, and the environment; and one food security degree. Cultural aspects of food are explored in such majors as gastronomy; ecogastronomy; and food, place, and culture (see Appendix A).

\section{Graduate Programs Identified}

We identified 58 graduate interdisciplinary foodrelated academic programs housed at 42 universities, with a full listing of these graduate programs in Appendix B. Of the 58 graduate interdisciplinary programs, $55(95 \%)$ provided online resources about their programs and course listings. After reviewing course listings for all 55 programs, the totals for each course category were calculated. We found that there were 991 courses in all that we organized into nine categories.

The most prevalent graduate school courses, as displayed in Figure 2, were in the biological and physical sciences $(n=183)$, usually in support of food science research. The second highest course category was in public health and nutrition ( $n=159)$, followed by government, policy, and economics $(n=138)$. Food Studies and Food Systems courses $(n=66)$ were eighth in prevalence. In order to assess the interdisciplinary nature of these food programs, we evaluated how many different course categories each program's classes belonged to. Within the nine course categories, 78 percent (43 of 55) of the programs offered courses in two to five categories, and 22 percent (12 of 55) offered courses in six to eight categories.

The interdisciplinary food-related academic program field is dynamic. While preparing this commentary for publication, we found that since our research was completed in 2015, more programs had emerged and some programs had been put on hold. We anticipate that the landscape has continued to change and that emergent programs will be identified and included in future research efforts.

\section{Discussion}

This exploratory research was undertaken to develop a snapshot of the interdisciplinary food- 
Figure 2. Interdisciplinary Food-Related Academic Graduate Program Courses by Category

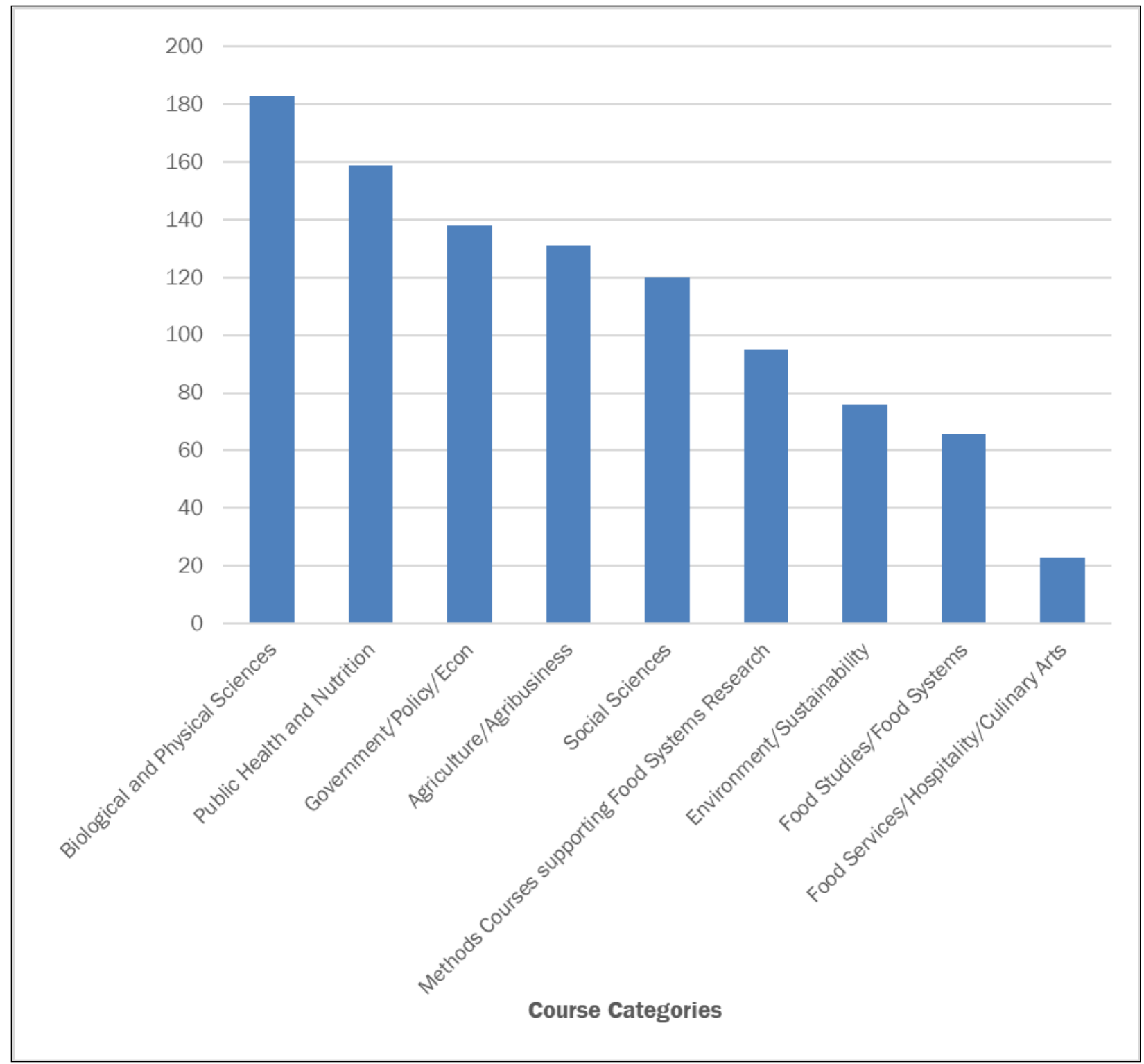

related academic programs in the United States to inform future investigations on the breadth of this growing field of research and study. We combined the practical knowledge our colleagues had of established food-related academic programs with a systematic online search for programs that met our eligibility criteria.

While we found many interdisciplinary foodrelated academic programs, our research yielded few truly interdisciplinary courses. Among graduate programs, we observed that many food studies and food systems programs, although offering courses in multiples disciplines, were primarily focused in one area of study. Instead of designing courses that included multiple disciplines into one course, there was a tendency to design programs where the multifaceted knowledge about food was acquired by students taking separate courses in a variety of disciplines. We believe that this course and program design may be due to the fact that many food studies and food systems programs originated in single 
disciplinary settings and are still growing into the field of interdisciplinary work. There is also the challenge of cost-effective methods to teach interdisciplinary courses, with issues such as funding faculty from single-discipline fields to co-teach an interdisciplinary course, finding funding for fulltime faculty, and hiring faculty trained and specializing in interdisciplinary work. Another explanation for this single-discipline structure stems from historical underpinnings. For instance, single disciplines sometimes have established themselves as the lead food-related authority in an institution and may approach collaboration with another discipline cautiously (Weissman et al., 2012). The addition of interdisciplinary food studies and food systems programs can also create conflict because this new discipline may be competing for the same sources of funding as the established single-discipline departments. For example, an agroecology program may compete for agriculture or environmental funding.

A limitation of our study was that it was a cross-sectional assessment of available interdisciplinary food-related academic programs. Our main search methods were to contact academic food studies and food systems experts and to search for programs using online resources. Schools and/or programs that were not well known, were newly established, or did not have an internet presence at the time of our data-gathering may not have been captured with these methods. In the future, it could prove beneficial to administer a survey to all existing programs with questions that could aid in characterizing their programs. A census could gather program details to give a more complete picture of the past, current, and future directions of the emerging field of food-related academic programs. In future research, more specific data should be asked regarding the age and stage of the program, the number of currently enrolled students, the number of graduates, the jobs that program graduates attain, and a more detailed course analysis (possibly even course syllabi). By learning more about these programs, we could develop typologies of foodrelated academic programs to expand or refine our current findings on interdisciplinary program types such as food studies, food systems, agroecology, and ecogastronomy. In addition, open-ended questions and select interviews could reveal details about the challenges of establishing and maintaining a program, including defining the program's niche or brand, the vision for the program, current opportunities, and prospective opportunities for collaboration.

\section{Conclusions}

The research presented here is a snapshot of the interdisciplinary food-related academic programs landscape that is emerging at universities across the country. Our preliminary findings reveal that many schools continue to focus their course offerings in traditional academic strengths, and this may indicate a need or opportunity to expand more interdisciplinary course offerings.

Metrics need to be developed for the emerging field of food-related academic programs that evaluate their curricula as well as the job attainment of graduates. Possible directions include developing metrics to assess in which fields students find employment, and determining if training prepares students for previously existing jobs exclusively or for new types of jobs and career paths. These data could be obtained through a survey of program graduates and could yield valuable information to accelerate the development of programs that better fulfill the needs of current and future students.

The widespread presence of interdisciplinary food-related academic programs in the U.S. identified in this formative study appears to have emerged fairly recently. These programs are likely developing in response to a growing sense of need to address what appears to be multiple social, environmental, and economic failings of the current food system. We hope that these academic programs will provide the pipeline of intellectual and human resources needed to solve these complex, interdisciplinary food-related problems.

\section{Acknowledgments}

The authors would like to acknowledge the contributions of Daniel Press, Ann Thrupp, Tom Tomich, Josephine Hau, and John Rafael, who helped us lay the foundation to our work, and of Jennifer Otten, Pamela Rhubart Berg, and Roni Neff, who provided expert reviews of our initial drafts. 


\section{References}

Berg, J., Nestle, M., \& Bentley, A. (2003). Food Studies. In S. H. Katz \& W. W. Weaver (Eds.), Encyclopedia of Food and Culture. New York: Charles Scribners \& Sons.

Boston University. (n.d.). Gastronomy programs. Retrieved from http://www.bu.edu/met/subject/gastronomy/

Cargill, K. (2005). Food studies in the curriculum: A model for interdisciplinary pedagogy. Food, Culture \& Society, 8(1), 115-123. https://doi.org/10.2752/155280105778055371

Godfray, H. C. J., Beddington, J. R., Crute, I. R., Haddad, L., Lawrence, D., Muir, J. F., . . Toulmin, C. (2010). Food security: The challenge of feeding 9 billion people. Science, 327(5967), 812-818. http://dx.doi.org/10.1126/science.1185383

Holt, S. (2015, September 22). Majoring in food: Colleges offering more courses, degrees [Blog post]. Civil Eats. Retrieved from https:// civileats.com/2015/09/22/majoring-in-food-colleges-offering-more-courses-degrees/

Jacobsen, K. L., Niewolny, K. L., Schroeder-Moreno, M. S., Van Horn, M., Harmon, A. H., Chen Fanslow, Y. H., ... Parr, D. (2012). Sustainable agriculture undergraduate degree programs: A land-grant university mission. Journal of Agriculture, Food Systems, and Community Development, 2(3), 13-26. http://dx.doi.org/10.5304/jafscd.2012.023.004

McIntyre, B. D., Herren, H. R., Wakhungu, J., \& Watson, R. T. E. (2009). Agriculture at a crossroads: The global report. Washington, D.C.: International Assessment of Agricultural Knowledge, Science, and Technology for Development (IAASTD).

Neff, R. (Ed.). (2014). Introduction to the U.S. food system: Public health, environment, and equity. San Francisco: Jossey-Bass.

Neff, R. A., Merrigan, K., \& Wallinga, D. (2015). A food systems approach to healthy food and agriculture policy. Health Affairs, 34(11), 1908-1915. http://dx.doi.org/10.1377/hlthaff.2015.0926

Nestle, M., \& McIntosh, W. A. (2010). Writing the food studies movement. Food, Culture \& Society, 13(2), $159-179$. http://dx.doi.org/10.2752/175174410X12633934462999

Pretty, J., Sutherland, W. J., Ashby, J., Auburn, J., Baulcombe, D., Bell, M., . . Pilgrim, S. (2010). The top 100 questions of importance to the future of global agriculture. International Journal of Agricultural Sustainability, 8(4), $219-236$. http://dx.doi.org/10.3763/ijas.2010.0534

Sobal, J., Khan, L. K., \& Bisogni, C. (1998). A conceptual model of the food and nutrition system. Social Science \& Medicine, 47(7), 853-863. https://doi.org/10.1016/S0277-9536(98)00104-X

Spiegel, J. E. (2012, April 13). Truly food for thought. The New York Times. Retrieved from http://www.nytimes.com/2012/04/15/education/edlife/truly-food-for-thought.html

Tomich, T. P., Brodt, S., Ferris, H., Galt, R., Horwath, W. R., Kebreab, E., . . Yang, L. (2011). Agroecology: A review from a global-change perspective. Annual Review of Environment and Resources, 36(1), 193-222. http://dx.doi.org/10.1146/annurev-environ-012110-121302

Weissman, E., Gantner, L., \& Narine, L. (2012). Building a food studies program: On-the-ground reflections from Syracuse University. Journal of Agriculture, Food Systems, and Community Development, 2(3), 79-89. http://dx.doi.org/10.5304/jafscd.2012.023.010

Whitmee, S., Haines, A., Beyrer, C., Boltz, F., Capon, A. G., de Souza Dias, B. F., . . Yach, D. (2015). Safeguarding human health in the Anthropocene epoch: Report of The Rockefeller Foundation- Lancet Commission on planetary health. The Lancet, 386(10007), 1973-2028. http://dx.doi.org/10.1016/S0140-6736(15)60901-1 


\section{Appendix A. Undergraduate Food-related Academic Programs: 2015 Snapshot}

\begin{tabular}{|c|c|c|c|}
\hline Institution Name & School/Department/Programs Involved & Degree Name & Degree Awarded \\
\hline $\begin{array}{l}\text { Appalachian State } \\
\text { University }\end{array}$ & Program of Sustainable Development & $\begin{array}{l}\text { Sustainable Development (BS) - } \\
\text { Agroecology and Sustainable } \\
\text { Agriculture Concentration }\end{array}$ & $\begin{array}{l}\mathrm{BS}^{\mathrm{a}} \\
\text { concentration }\end{array}$ \\
\hline \multirow{2}{*}{$\begin{array}{l}\text { California State } \\
\text { Polytechnic University, } \\
\text { San Luis Obispo }\end{array}$} & Department of Food Science and Nutrition & Nutrition & BS \\
\hline & $\begin{array}{l}\text { College of Agriculture, Food and } \\
\text { Environmental Sciences (CAFES), Center for } \\
\text { Sustainability }\end{array}$ & Sustainable Agriculture & Minor \\
\hline $\begin{array}{l}\text { California State } \\
\text { University, Stanislaus }\end{array}$ & $\begin{array}{l}\text { College of the Arts, Humanities, and Social } \\
\text { Sciences; Department of Agricultural } \\
\text { Studies }\end{array}$ & $\begin{array}{l}\text { Agricultural Studies, } \\
\text { Permaculture }\end{array}$ & BS \\
\hline \multirow[t]{2}{*}{ Clemson University } & $\begin{array}{l}\text { College of Agriculture, Forestry, and Life } \\
\text { Sciences; School of Food, Nutrition, and } \\
\text { Packaging Sciences }\end{array}$ & $\begin{array}{l}\text { Food Science; Packaging } \\
\text { Science }\end{array}$ & BS \\
\hline & $\begin{array}{l}\text { College of Entomology, Soil, and Plant } \\
\text { Sciences }\end{array}$ & $\begin{array}{l}\text { Soils and Sustainable Crop } \\
\text { Systems }\end{array}$ & BS \\
\hline College of the Atlantic & None specified & Farming and Food Systems & BS \\
\hline $\begin{array}{l}\text { Culinary Institute of } \\
\text { America }\end{array}$ & New York Campus & Applied Food Studies & BPS $^{b}$ \\
\hline $\begin{array}{l}\text { City University New York, } \\
\text { Hunter College }\end{array}$ & School of Urban Public Health & Nutrition and Food Science & BS \\
\hline Delaware Valley College & Department of Plant Science & $\begin{array}{l}\text { Sustainable Agriculture } \\
\text { Systems }\end{array}$ & BS \\
\hline \multirow[t]{3}{*}{ Evergreen State College } & None specified & Food, Health, and Sustainability & $\mathrm{BA}^{\mathrm{c}}$ or $\mathrm{BS}$ \\
\hline & & Food, Place, and Culture & $\mathrm{BA}$ or $\mathrm{BS}$ \\
\hline & & $\begin{array}{l}\text { Practice of Sustainable } \\
\text { Agriculture }\end{array}$ & $\mathrm{BA}$ or $\mathrm{BS}$ \\
\hline Ferrum College & $\begin{array}{l}\text { School of Natural Sciences and } \\
\text { Mathematics, Department of Agricultural } \\
\text { Sciences }\end{array}$ & $\begin{array}{l}\text { Agriculture with emphasis in } \\
\text { Agroecology }\end{array}$ & $\begin{array}{l}\text { BS emphasis } \\
\text { area }\end{array}$ \\
\hline Fort Lewis College & $\begin{array}{l}\text { School of Natural and Behavioral Sciences, } \\
\text { Department of Biology and Agriculture }\end{array}$ & $\begin{array}{l}\text { Agroecology/Sustainable } \\
\text { Agriculture }\end{array}$ & Minor \\
\hline George Mason University & College of Health and Human Services & $\begin{array}{l}\text { Global and Community Health, } \\
\text { Nutrition Concentration }\end{array}$ & BS \\
\hline $\begin{array}{l}\text { Georgia Southern } \\
\text { University }\end{array}$ & College of Health and Human Sciences & Nutrition and Food Science & BS \\
\hline Green Mountain College & None specified & $\begin{array}{l}\text { Sustainable Agriculture and } \\
\text { Food Production }\end{array}$ & BA \\
\hline Kentucky State University & $\begin{array}{l}\text { College of Agriculture, Food Science, and } \\
\text { Sustainable Systems }\end{array}$ & $\begin{array}{l}\text { Agriculture, Food, and } \\
\text { Environment }\end{array}$ & BS \\
\hline $\begin{array}{l}\text { Le Cordon Bleu of } \\
\text { Culinary Arts (USA) } \\
\text { (online) }\end{array}$ & Le Cordon Bleu & $\begin{array}{l}\text { Culinary Arts/ Pâtisserie and } \\
\text { Baking Program/Hospitality \& } \\
\text { Restaurant Management } \\
\text { Program/Culinary Management } \\
\text { Online }\end{array}$ & BA/Associates \\
\hline
\end{tabular}




\begin{tabular}{|c|c|c|c|}
\hline Institution Name & School/Department/Programs Involved & Degree Name & Degree Awarded \\
\hline \multirow[t]{2}{*}{ Lipscomb University } & $\begin{array}{l}\text { College of Leadership and Public Service: } \\
\text { Institute for Sustainable Practice }\end{array}$ & $\begin{array}{l}\text { Environmental and } \\
\text { Sustainability Science, focus on } \\
\text { Agroecology }\end{array}$ & BA \\
\hline & Department of Nutrition & Food Systems Management & BS \\
\hline Loyola University Chicago & Institute of Environmental Sustainability & $\begin{array}{l}\text { Environmental Science: Food } \\
\text { Systems and Sustainable } \\
\text { Agriculture }\end{array}$ & BS \\
\hline \multirow[t]{2}{*}{ Michigan State University } & $\begin{array}{l}\text { Department of Food Science and Human } \\
\text { Nutrition, College of Agriculture and Natural } \\
\text { Resources }\end{array}$ & $\begin{array}{l}\text { Food Science and Human } \\
\text { Nutrition }\end{array}$ & BS \\
\hline & $\begin{array}{l}\text { College of Agriculture and Natural } \\
\text { Resources, Department of Plant, Soil, and } \\
\text { Microbial Sciences }\end{array}$ & $\begin{array}{l}\text { Sustainable Agriculture and } \\
\text { Food Systems }\end{array}$ & Minor \\
\hline Montana State University & $\begin{array}{l}\text { Colleges of Agriculture and Education, } \\
\text { Health and Human Development }\end{array}$ & $\begin{array}{l}\text { Sustainable Food and } \\
\text { Bioenergy Systems }\end{array}$ & BS \\
\hline Montclair State University & $\begin{array}{l}\text { College of Education and Human Services; } \\
\text { Department of Nutrition and Food Science }\end{array}$ & $\begin{array}{l}\text { Nutrition and Food Science with } \\
\text { a concentration in Food } \\
\text { Systems }\end{array}$ & BS \\
\hline Morningside College & $\begin{array}{l}\text { Regina Roth Applied Agricultural and Food } \\
\text { Studies }\end{array}$ & $\begin{array}{l}\text { Applied Agricultural and Food } \\
\text { Studies }\end{array}$ & BA, BS, minor \\
\hline $\begin{array}{l}\text { New School for Public } \\
\text { Engagement }\end{array}$ & The New School For Public Engagement & Food Studies & $\mathrm{BA}$ or BS \\
\hline \multirow[t]{2}{*}{$\begin{array}{l}\text { North Carolina State } \\
\text { University }\end{array}$} & Department of Crop Science & $\begin{array}{l}\text { Crop science with } \\
\text { concentrations in: Agroecology, } \\
\text { Agronomic Business, Agronomic } \\
\text { Science, Crop Biotechnology, } \\
\text { Crop Production }\end{array}$ & BS \\
\hline & Department of Soil Science & Soil Science & BS \\
\hline The New School & Schools for Public Engagement & Food Studies & $\mathrm{BA}$ or BS \\
\hline \multirow[t]{2}{*}{ New York University } & $\begin{array}{l}\text { Steinhardt School of Culture, Education, } \\
\text { and Human Development; Department of } \\
\text { Nutrition, Food Studies, and Public Health }\end{array}$ & Food Studies & BS \\
\hline & & Nutrition and Dietetics & BS \\
\hline Ohio State University & $\begin{array}{l}\text { College of Food, Agricultural, and } \\
\text { Environmental Sciences }\end{array}$ & $\begin{array}{l}\text { Environment, Economy, } \\
\text { Development, and } \\
\text { Sustainability }\end{array}$ & BS and minor \\
\hline $\begin{array}{l}\text { Pennsylvania State } \\
\text { University }\end{array}$ & $\begin{array}{l}\text { College of Agricultural Sciences, Plant } \\
\text { Science }\end{array}$ & Plant Sciences & BS \\
\hline Prescott College & None specified & $\begin{array}{l}\text { Environmental Studies and } \\
\text { Sustainability-Agroecology }\end{array}$ & BS \\
\hline \multirow[t]{2}{*}{ Purdue University } & $\begin{array}{l}\text { College of Agriculture, Department of Food } \\
\text { Science }\end{array}$ & Food Science & BS \\
\hline & & Culinary Science & BS \\
\hline $\begin{array}{l}\text { Ramapo College of New } \\
\text { Jersey }\end{array}$ & $\begin{array}{l}\text { School of Social Science and Human } \\
\text { Services }\end{array}$ & Food Studies & Minor \\
\hline
\end{tabular}


Journal of Agriculture, Food Systems, and Community Development

ISSN: 2152-0801 online

http://www.foodsystemsjournal.org

\begin{tabular}{|c|c|c|c|}
\hline Institution Name & School/Department/Programs Involved & Degree Name & Degree Awarded \\
\hline Rutgers & $\begin{array}{l}\text { Department of Food Science, School of } \\
\text { Environmental and Biological Science }\end{array}$ & Food Science & BS \\
\hline Stanford University & $\begin{array}{l}\text { School of Earth, Energy, and Environmental } \\
\text { Sciences; Earth Systems Program }\end{array}$ & $\begin{array}{l}\text { Sustainable Food and } \\
\text { Agriculture Track }\end{array}$ & BS track \\
\hline Sterling College & Sterling College & Sustainable Food Systems & BA \\
\hline \multirow[t]{3}{*}{ Syracuse University } & $\begin{array}{l}\text { Department of Public Health, Food Studies, } \\
\text { and Nutrition }\end{array}$ & Nutrition & BS \\
\hline & & Nutrition Science & BS \\
\hline & & Food Studies & BS \\
\hline $\begin{array}{l}\text { University of California, } \\
\text { Berkeley }\end{array}$ & $\begin{array}{l}\text { College of Natural Resources (CNR), } \\
\text { Department of Environmental Science, } \\
\text { Policy \& Management (ESPM) }\end{array}$ & Food Systems Minor & Minor \\
\hline \multirow[t]{3}{*}{$\begin{array}{l}\text { University of California, } \\
\text { Davis }\end{array}$} & Agricultural Sustainability Institute & $\begin{array}{l}\text { Sustainable Agriculture and } \\
\text { Food Systems }\end{array}$ & BS \\
\hline & $\begin{array}{l}\text { Department of Agricultural and Resources } \\
\text { Economics }\end{array}$ & Agricultural Economics & BS \\
\hline & $\begin{array}{l}\text { College of Agricultural and Environmental } \\
\text { Sciences, Department of Food Science and } \\
\text { Technology }\end{array}$ & Food Science & BS \\
\hline $\begin{array}{l}\text { University of California, } \\
\text { Santa Cruz }\end{array}$ & College of Environmental Studies & $\begin{array}{l}\text { Environmental Studies, } \\
\text { Agroecology and Sustainable } \\
\text { Agriculture Emphasis }\end{array}$ & BS \\
\hline Unity College & $\begin{array}{l}\text { The Center for Sustainability and Global } \\
\text { Change }\end{array}$ & Sustainable Agriculture & BS \\
\hline University of Florida & Horticultural Sciences Department & Horticultural Science & BS and minor \\
\hline University of Georgia & $\begin{array}{l}\text { College of Agricultural and Environmental } \\
\text { Science, Department of Food Science and } \\
\text { Technology }\end{array}$ & Food Science and Technology & BS \\
\hline $\begin{array}{l}\text { University of Hawaii, West } \\
\text { O'ahu }\end{array}$ & Bachelor of Applied Sciences Programs & $\begin{array}{l}\text { Sustainable Community Food } \\
\text { Systems Concentration }\end{array}$ & $\begin{array}{l}\text { BAS }^{d} \\
\text { concentration }\end{array}$ \\
\hline University of Kentucky & $\begin{array}{l}\text { College of Agriculture, Food, and } \\
\text { Environment }\end{array}$ & Sustainable Agriculture & BS and minor \\
\hline University of Maine & $\begin{array}{l}\text { Departments of Plant, Soil and } \\
\text { Environmental Sciences, Biology, and } \\
\text { Resource Economics and Policy; } \\
\text { Sustainable Agriculture Program }\end{array}$ & Sustainable Agriculture & BS \\
\hline $\begin{array}{l}\text { University of } \\
\text { Massachusetts, Amherst }\end{array}$ & Stockbridge School of Agriculture & Sustainable Food and Farming & BS \\
\hline University of Michigan & College of Literature, Science and Arts & $\begin{array}{l}\text { Sustainability Food Systems } \\
\text { Minor }\end{array}$ & Minor \\
\hline University of Minnesota & Institute for Sustainable Agriculture & $\begin{array}{l}\text { Sustainable Agricultural } \\
\text { Systems }\end{array}$ & Minor \\
\hline University of Missouri & $\begin{array}{l}\text { College of Agriculture, Food, and Natural } \\
\text { Resources; Department of Agriculture }\end{array}$ & Sustainable Agriculture & BS and minor \\
\hline
\end{tabular}




\begin{tabular}{|c|c|c|c|}
\hline Institution Name & School/Department/Programs Involved & Degree Name & Degree Awarded \\
\hline University of Montana & $\begin{array}{l}\text { College of Humanities and Sciences, } \\
\text { Environmental Studies Department }\end{array}$ & $\begin{array}{l}\text { Environmental Studies, } \\
\text { Sustainable Food and Farming } \\
\text { Emphasis }\end{array}$ & BA emphasis \\
\hline \multirow{2}{*}{$\begin{array}{l}\text { University of New } \\
\text { Hampshire }\end{array}$} & Dual Degree in EcoGastronomy & EcoGastronomy & Dual Degree \\
\hline & Sustainable Agriculture and Food Systems & $\begin{array}{l}\text { Sustainable Agriculture and } \\
\text { Food Systems }\end{array}$ & BS, BA \\
\hline \multirow{2}{*}{$\begin{array}{l}\text { The University of } \\
\text { Southern Mississippi }\end{array}$} & \multirow[t]{2}{*}{ Department of Nutrition and Food Systems } & Nutrition Science & BS \\
\hline & & Nutrition and Dietetics & BS \\
\hline University of Tennessee & $\begin{array}{l}\text { Institute for Agriculture, Department of } \\
\text { Plant Sciences }\end{array}$ & Organic Production & BS concentration \\
\hline \multirow[t]{2}{*}{ University of Vermont } & Plant and Soil Science & Ecological Agriculture & BS and minor \\
\hline & Food Systems Initiative & Food Systems Minor & Minor \\
\hline University of Washington & $\begin{array}{l}\text { School of Public Health, Nutritional } \\
\text { Sciences Program }\end{array}$ & Nutritional Sciences & Minor \\
\hline $\begin{array}{l}\text { University of Wisconsin, } \\
\text { Madison }\end{array}$ & Department of Food Science & Food Science & BS \\
\hline $\begin{array}{l}\text { University of Wisconsin, } \\
\text { Stout }\end{array}$ & Food Science and Technology Program & Food Science and Technology & BS \\
\hline University of Wyoming & $\begin{array}{l}\text { Department of Plant Sciences and } \\
\text { Ecosystems Science and Management }\end{array}$ & Agroecology & BS and minor \\
\hline $\begin{array}{l}\text { Virginia Polytechnic } \\
\text { Institute and State } \\
\text { University }\end{array}$ & $\begin{array}{l}\text { Departments of Horticulture; Agricultural, } \\
\text { Leadership, and Community Education; } \\
\text { Human Nutrition, Foods, and Exercise; } \\
\text { Agriculture and Life Sciences; Animal and } \\
\text { Poultry Sciences; Crop and Soil } \\
\text { Environmental Sciences; Plant Pathology, } \\
\text { Physiology, and Weed Science }\end{array}$ & $\begin{array}{l}\text { Civic Agriculture and Food } \\
\text { Systems }\end{array}$ & Minor \\
\hline Warren Wilson College & Department of Environmental Studies & $\begin{array}{l}\text { Environmental Studies with } \\
\text { emphasis on Sustainable } \\
\text { Agriculture }\end{array}$ & $\begin{array}{l}\text { BA, BS } \\
\text { concentration }\end{array}$ \\
\hline \multirow[t]{5}{*}{$\begin{array}{l}\text { Washington State } \\
\text { University }\end{array}$} & $\begin{array}{l}\text { College of Agricultural, Human, and Natural } \\
\text { Resource Sciences }\end{array}$ & Organic Agricultural Systems & BS \\
\hline & & $\begin{array}{l}\text { Agricultural Technology and } \\
\text { Production Management }\end{array}$ & BS \\
\hline & & Agricultural Education & BS \\
\hline & & $\begin{array}{l}\text { Agricultural and Food Business } \\
\text { Economics }\end{array}$ & BS \\
\hline & & Agricultural and Food Security & BS \\
\hline $\begin{array}{l}\text { Western Washington } \\
\text { University }\end{array}$ & $\begin{array}{l}\text { Fairhaven College of Interdisciplinary } \\
\text { Studies }\end{array}$ & $\begin{array}{l}\text { Self-Designed Concentration in } \\
\text { Sustainable Agriculture }\end{array}$ & BA concentration \\
\hline Xavier University (in Ohio) & Land, Agriculture, and Community & Land, Farming, and Community & BA \\
\hline
\end{tabular}

a Bachelor of Science; b Bachelor of Professional Studies; c Bachelor of Arts; d Bachelor of Applied Sciences 


\section{Appendix B. Graduate Food-related Academic Programs: 2015 Snapshot}

\begin{tabular}{|c|c|c|c|}
\hline Institution Name & School/Department/Programs Involved & Degree Name & Degree Awarded \\
\hline \multirow[t]{2}{*}{ Boston University } & \multirow[t]{2}{*}{ Metropolitan College } & Gastronomy & $\mathrm{MLA}^{\mathrm{a}}$ \\
\hline & & Food Studies & Certificate \\
\hline Chatham University & Falk School of Sustainability & Food Studies & $\mathrm{MA}^{\mathrm{b}}$ \\
\hline College of the Atlantic & None specified & Sustainable Food Systems & MPhilc \\
\hline \multirow[t]{2}{*}{ George Mason University } & $\begin{array}{l}\text { College of Health and Human Services; } \\
\text { Department of Nutrition and Food } \\
\text { Studies, Department of Geography and } \\
\text { Geoinformation Science }\end{array}$ & Food Security & Certificate \\
\hline & Not specified & Sustainable Food Systems & $\mathrm{MS}^{\mathrm{d}}$ \\
\hline Indiana State University & $\begin{array}{l}\text { College of Health and Human Services, } \\
\text { Department of Applied Health Sciences }\end{array}$ & Public Health Nutrition & $\begin{array}{l}\text { MS } \\
\text { Concentration }\end{array}$ \\
\hline $\begin{array}{l}\text { Indiana University, } \\
\text { Bloomington }\end{array}$ & $\begin{array}{l}\text { Departments of Anthropology, Archeology, } \\
\text { Political Science, Nutrition, Biology, } \\
\text { Geography, Comparative Literature }\end{array}$ & Anthropology of Food & $\mathrm{PhDe}$ \\
\hline lowa State University & Sustainable Agriculture & Sustainable Agriculture & MS, PhD \\
\hline Johns Hopkins University & Bloomberg School of Public Health & $\begin{array}{l}\text { Food System, Environment and } \\
\text { Public Health }\end{array}$ & Certificate \\
\hline Kansas State University & $\begin{array}{l}\text { Urban Food Systems; Horticulture, } \\
\text { Forestry, and Recreation }\end{array}$ & $\begin{array}{l}\text { Horticulture with an emphasis in } \\
\text { Food Systems }\end{array}$ & MS \\
\hline $\begin{array}{l}\text { Kentucky State } \\
\text { University }\end{array}$ & $\begin{array}{l}\text { College of Agriculture, Food Science, and } \\
\text { Sustainable Systems }\end{array}$ & Environmental Studies & MS \\
\hline $\begin{array}{l}\text { Marylhurst College } \\
\text { (Online with some on- } \\
\text { campus courses) }\end{array}$ & Department of Food Systems and Society & Food Systems and Society & MS \\
\hline \multirow[t]{2}{*}{$\begin{array}{l}\text { Michigan State } \\
\text { University }\end{array}$} & Plant, Soil and Microbial Sciences & $\begin{array}{l}\text { Ecological Food \& Farming } \\
\text { Systems }\end{array}$ & MS, PhD \\
\hline & $\begin{array}{l}\text { Department of Agricultural, Food, and } \\
\text { Resource Economics }\end{array}$ & $\begin{array}{l}\text { Agricultural, Food, and Resource } \\
\text { Economics }\end{array}$ & $\begin{array}{l}\text { MS, PhD, Dual } \\
\text { Degrees }\end{array}$ \\
\hline $\begin{array}{l}\text { Montana State } \\
\text { University }\end{array}$ & $\begin{array}{l}\text { Department of Health and Human } \\
\text { Development }\end{array}$ & $\begin{array}{l}\text { Food, Family, and Community } \\
\text { Health Sciences Option; } \\
\text { Sustainable Food Systems } \\
\text { Program }\end{array}$ & MS \\
\hline $\begin{array}{l}\text { New Mexico State } \\
\text { University }\end{array}$ & Anthropology & Food Studies & MA Minor \\
\hline New York University & $\begin{array}{l}\text { Steinhardt School of Culture, Education, } \\
\text { and Human Development; The } \\
\text { Department of Nutrition, Food Studies, } \\
\text { and Public Health }\end{array}$ & $\begin{array}{l}\text { Food Studies, Global Public } \\
\text { Health/Nutrition and Dietetics, } \\
\text { Global Public Health/Food } \\
\text { Studies, Nutrition }\end{array}$ & MS, PhD \\
\hline \multirow[t]{2}{*}{$\begin{array}{l}\text { North Dakota State } \\
\text { University }\end{array}$} & Agribusiness and Applied Economics & $\begin{array}{l}\text { Agribusiness and Applied } \\
\text { Economics }\end{array}$ & MS \\
\hline & $\begin{array}{l}\text { Plant Sciences, Veterinary and } \\
\text { Microbiological Sciences, and Agricultural } \\
\text { and Biosystems Engineering }\end{array}$ & Cereal Sciences & MS, PhD \\
\hline
\end{tabular}




\begin{tabular}{|c|c|c|c|}
\hline Institution Name & School/Department/Programs Involved & Degree Name & Degree Awarded \\
\hline & $\begin{array}{l}\text { School of Natural Resource Sciences; } \\
\text { Departments of Entomology, } \\
\text { Environmental and Conservation } \\
\text { Sciences, and Natural Resources } \\
\text { Management }\end{array}$ & Entomology & MS, PhD \\
\hline & Agribusiness and Applied Economics & International Agribusiness & MS \\
\hline & $\begin{array}{l}\text { School of Food Systems; faculty } \\
\text { participants from the Colleges of } \\
\text { Agriculture, Food Systems, and Natural } \\
\text { Resources; Arts, Humanities, and Social } \\
\text { Sciences; Engineering and Architecture; } \\
\text { Human Development and Education; and } \\
\text { Science and Mathematics }\end{array}$ & $\begin{array}{l}\text { International Infectious Disease } \\
\text { Management and Biosecurity }\end{array}$ & MS, PhD \\
\hline & Plant Pathology & Plant Pathology & MS, PhD \\
\hline & Plant Sciences & Plant Sciences & MS, PhD \\
\hline & $\begin{array}{l}\text { Agriculture, Food Systems, and Natural } \\
\text { Resources; Arts, Humanities and Social } \\
\text { Sciences; Engineering and Architecture; } \\
\text { Human Development and Education; and } \\
\text { Science and Math }\end{array}$ & Food Safety & MS, PhD \\
\hline & Agricultural and Biosystems Engineering & $\begin{array}{l}\text { Agriculture and Biosystems } \\
\text { Engineering }\end{array}$ & MS, PhD \\
\hline Ohio State University & $\begin{array}{l}\text { Environmental Science Graduate Program } \\
\text { with faculty from Colleges of Biological } \\
\text { Sciences; Engineering; Food, Agricultural, } \\
\text { and Environmental Sciences; } \\
\text { Mathematical and Physical Sciences; } \\
\text { Medicine; Social and Behavioral Sciences; } \\
\text { and Veterinary Medicine }\end{array}$ & $\begin{array}{l}\text { Environmental Science, } \\
\text { Agrosystems Science Graduate } \\
\text { Specialization }\end{array}$ & MS, PhD \\
\hline Rutgers & Food Sciences & Food Science & MS, PhD \\
\hline Santa Clara University & $\begin{array}{l}\text { Leavey School of Business, Food and } \\
\text { Agribusiness Institute }\end{array}$ & $\begin{array}{l}\text { Food and Agribusiness } \\
\text { Concentration }\end{array}$ & $\begin{array}{l}\text { MBA } \\
\text { Concentration }\end{array}$ \\
\hline Syracuse University & Nutrition Science and Dietetics & Nutrition Science & MA or MS \\
\hline Texas A \& M University & $\begin{array}{l}\text { The Departments of Soil \& Crop Sciences, } \\
\text { Agricultural Economics, Veterinary } \\
\text { Pathobiology, and Veterinary Physiology \& } \\
\text { Pharmacology }\end{array}$ & $\begin{array}{l}\text { Regulatory Science in Food } \\
\text { Systems }\end{array}$ & Certificate \\
\hline \multirow{2}{*}{$\begin{array}{l}\text { Texas Women's } \\
\text { University }\end{array}$} & \multirow[t]{2}{*}{ Nutrition \& Food Sciences } & Food Science & MS \\
\hline & & Food Systems Administration & MS \\
\hline Tufts University (Online) & $\begin{array}{l}\text { Friedman School of Nutrition Science and } \\
\text { Policy }\end{array}$ & $\begin{array}{l}\text { Sustainable Agriculture and Food } \\
\text { Systems }\end{array}$ & Certificate \\
\hline \multirow{2}{*}{$\begin{array}{l}\text { University of California, } \\
\text { Berkeley }\end{array}$} & School of Public Health & Public Health Nutrition & $\mathrm{MPH}^{f}$ \\
\hline & College of Natural Resources & $\begin{array}{l}\text { Environmental Science, Policy, } \\
\text { and Management }\end{array}$ & $\mathrm{PhD}$ \\
\hline $\begin{array}{l}\text { University of California, } \\
\text { Davis }\end{array}$ & Food Science and Technology & Food Science & MS, PhD \\
\hline
\end{tabular}


Journal of Agriculture, Food Systems, and Community Development

ISSN: 2152-0801 online

http://www.foodsystemsjournal.org

\begin{tabular}{|c|c|c|c|}
\hline Institution Name & School/Department/Programs Involved & Degree Name & Degree Awarded \\
\hline $\begin{array}{l}\text { University of California, } \\
\text { Santa Cruz }\end{array}$ & Environmental Studies Department & $\begin{array}{l}\text { Environmental Studies with a } \\
\text { focus on Agroecology and } \\
\text { Sustainable Agriculture }\end{array}$ & PhD \\
\hline $\begin{array}{l}\text { University of } \\
\text { Massachusetts }\end{array}$ & College of Natural Sciences & $\begin{array}{l}\text { Sustainability Science with a } \\
\text { focus on Sustainably Food } \\
\text { Systems and Agriculture }\end{array}$ & MS \\
\hline University of Michigan & $\begin{array}{l}\text { School of Natural Resources and } \\
\text { Environment }\end{array}$ & $\begin{array}{l}\text { Sustainable Systems, Food } \\
\text { Systems Theme }\end{array}$ & MS \\
\hline \multirow[t]{2}{*}{ University of Minnesota } & \multirow[t]{2}{*}{$\begin{array}{l}\text { Minnesota Institute for Sustainable } \\
\text { Agriculture }\end{array}$} & Sustainable Agricultural Systems I & $\begin{array}{l}\text { Minor for MS, MA } \\
\& \mathrm{PhD}\end{array}$ \\
\hline & & Food Science and Nutrition & MS, PhD \\
\hline University of Missouri & $\begin{array}{l}\text { Food Science College of Agriculture, Food } \\
\text { and Natural Resources }\end{array}$ & Food Science & $\mathrm{MS}, \mathrm{PhD}$ \\
\hline $\begin{array}{l}\text { University of Missouri } \\
\text { (Online) }\end{array}$ & Center for Agroforestry & Agroforestry & MS \\
\hline University of Montana & College of Humanities and Sciences & $\begin{array}{l}\text { Environmental Studies, } \\
\text { Sustainable Food and Farming } \\
\text { Emphasis }\end{array}$ & MS emphasis \\
\hline $\begin{array}{l}\text { University of North } \\
\text { Carolina, Chapel Hill }\end{array}$ & Department of Anthropology & $\begin{array}{l}\text { Food, Environment, and } \\
\text { Sustainability }\end{array}$ & Concentration \\
\hline $\begin{array}{l}\text { University of North Texas } \\
\text { School of Public Health }\end{array}$ & School of Public Health & $\begin{array}{l}\text { Certificate in Food Security and } \\
\text { Public Health }\end{array}$ & Certificate \\
\hline University of Oregon & $\begin{array}{l}\text { College of Arts and Sciences, } \\
\text { Environmental Studies Program }\end{array}$ & Food Studies & Specialization \\
\hline \multirow[t]{3}{*}{ University of the Pacific } & \multirow[t]{3}{*}{ College of the Pacific } & Food Studies & MA \\
\hline & & \multicolumn{2}{|l|}{ Food Systems Graduate Program MS } \\
\hline & & $\begin{array}{l}\text { Animal, Nutrition, and Food } \\
\text { Science }\end{array}$ & $\mathrm{PhD}$ \\
\hline $\begin{array}{l}\text { University of Rhode } \\
\text { Island }\end{array}$ & $\begin{array}{l}\text { College of the Environment and Life } \\
\text { Sciences }\end{array}$ & $\begin{array}{l}\text { Biological and Environmental } \\
\text { Systems, Specialization in } \\
\text { Sustainable Agriculture and Food } \\
\text { Systems }\end{array}$ & $\begin{array}{l}\text { MS, PhD } \\
\text { Specialization }\end{array}$ \\
\hline $\begin{array}{l}\text { The University of } \\
\text { Southern Mississippi }\end{array}$ & $\begin{array}{l}\text { College of Health; Department of Nutrition } \\
\& \text { Food Systems }\end{array}$ & Nutrition and Food Systems & MS \\
\hline University of Vermont & Nutrition and Food Sciences Department & Nutrition and Food Studies & MS \\
\hline $\begin{array}{l}\text { University of Wisconsin- } \\
\text { Madison }\end{array}$ & College of Agricultural and Life Sciences & Agroecology & MS \\
\hline $\begin{array}{l}\text { University of Wisconsin- } \\
\text { Stevens Point }\end{array}$ & $\begin{array}{l}\text { School of Health Promotion and Human } \\
\text { Development }\end{array}$ & $\begin{array}{l}\text { Sustainable and Resilient Food } \\
\text { Systems }\end{array}$ & MS \\
\hline $\begin{array}{l}\text { Washington State } \\
\text { University }\end{array}$ & $\begin{array}{l}\text { College of Agricultural, Human, and } \\
\text { Natural Resource Sciences; Department } \\
\text { of Horticulture }\end{array}$ & Agriculture & MS \\
\hline
\end{tabular}

a Master of Liberal Arts; ${ }^{b}$ Master of Arts; c Master of Philosophy; ${ }^{d}$ Master of Science; e Doctor of Philosophy; ${ }^{\mathrm{f}}$ Master of Public Health 